Counsellia: Jurnal Bimbingan dan Konseling 8 (2) 122-134 |November 2018

Copyright (O2017 Universitas PGRI Madiun

ISSN: 2088-3072 (Print) / 2477-5886 (Online)

Available online at: http://e-journal.unipma.ac.id/index.php/JBK

DOI: $10.25273 /$ counsellia.v8i2.3038

\title{
Penurunan perilaku seksual pranikah melalui Tazkiyatun Nafs berbasis REBT
}

\author{
Sri Hartati ${ }^{1}$, Eva Latipah ${ }^{2}$, Aprezo Pardodi Maba ${ }^{3}$ \\ ${ }^{1}$ Institut Agama Islam Ma`arif Nahdlatul Ulama Metro Lampung \\ srihartati2191@gmail.com \\ ${ }^{2}$ Universitas Islam Negeri Sunan Kalijaga Yogyakarta \\ evalatipah@yahoo.co.id \\ ${ }^{3}$ Institut Agama Islam Ma`arif Nahdlatul Ulama Metro Lampung \\ aprezopm@gmail.com
}

\begin{abstract}
Abstrak
Rendahnya internalisasi nilai-nilai etika dan moral dikalangan remaja terutama mengenai perilaku seksual pranikah, menjadi latarbelakang dilakukannya studi eksperimen dengan rancangan pretest-posttest nonequivalent yang melibatkan dua kelompok remaja. Penelitian ini dilakukan untuk menentukan signifikansi penurunan perilaku seksual pranikah melalui tazkiyatun nafs berbasis REBT. Kajian penurunan perilaku seksual pranikah melalui tazkiyatun nafs berbasis REBT dilakukan dengan mengendalikan perbedaan perilaku seksual pranikah sebelum perlakuan selain itu ditinjau berdasarkan pengaruh jenis kelamin terhadap tazkiyatun nafs berbasis REBT. Ancova dan Two-way anova dijadikan sebagai Teknik analisis data. Ada dua temuan dalam penelitian ini, yang pertama terjadi penurunan signifikan perilaku seksual pranikah setelah mendapatkan layanan tazkiyatun nafs berbasis REBT. Kedua, jenis kelamin tidak mempengaruhi keefektifan tazkiyatun nafs berbasis REBT. Tazkiyatun nafs berbasis REBT dapat menjadi alternatif untuk menurunkan perilaku seksual pranikah remaja.
\end{abstract}

Kata kunci: Tazkiyatun nafs, REBT, Perilaku Seksual Pranikah

\begin{abstract}
The lack of internalization of ethical values and morals among adolescence especially premarital sexual behavior, became background of the experiment study with pretestposttest design nonequivalent involving two groups of adolescence. This research was conducted to determine the significance of decrease in premarital sexual behavior through tazkiyatun nafs based REBT. Study of decrease in premarital sexual behavior through tazkiyatun nafs based REBT is done by controlling premarital sexual behavior differences before treatment, then reviewed based on the influence of gender against nafs tazkiyatun-based REBT. Ancova and two-way anova was used as data analysis techniques. There are two findings in this study, first there is a significant decrease in premarital sexual behavior after receiving tazkiyatun nafs service based REBT. Second, gender does not affect the effectiveness of tazkiyatun nafs based REBT. Tazkiyatun nafs based REBT could become an alternative to reduce adolescence premarital sexual behavior.
\end{abstract}

Keywords: Tazkiyatun Nafs, REBT, Premarital Sexual Behavior 



\section{PENDAHULUAN}

Perkembangan

remaja

merupakan masa yang paling penting, karena pada masa ini remaja mengalami masa perubahan dari masa kanak-kanak ke kehidupan dewasa (Hurlock 2007). Remaja berada pada tahap kehidupan yang melibatkan mereka untuk mempelajari cara-cara berpikir dan memiliki perilaku baru menuju berbagai kejadian secara adaptif. Pada masa peralihan tersebut remaja mengalami berbagai macam fase perkembangan yang harus di jalani dan nantinya akan berpengaruh terhadap tingkah laku remaja tersebut (Hartati 2017a).

Salah satu perkembangan remaja yang sangat fenomenal adalah terbentuknya peningkatan keinginan dan dorongan remaja terhadap seksual (Desmita 2012). Adanya peningkatan keinginan seksual pada remaja dipengaruhi beberapa faktor diantaranya kematangan organ-organ seksual dan perubahan hormonal sehingga memunculkan dorongan seksual dalam diri remaja. Untuk melepaskan faktor dorongan seksual tersebut, remaja mencoba mengekspresikannya dalam berbagai bentuk perilaku seksual melalui aktivitas berpacaran seperti berpegangan tangan, berciuman, bercumbu sampai kepada melakukan kontak seksual.

Perilaku seksual merupakan segala bentuk perilaku individu yang yang disebabkan oleh adanya hasrat seksual terhadap seseorang baik laki- laki maupun perempuan. Bentuk perilaku tersebut sangat beragam mulai dari perasaan tertarik terhadap seseorang dan adanya keinginan untuk mengenal seseorang lebih dalam sampai berpacaran, rayuan dan hubungan seks. Sasaran seksualnya bisa langsung kepada seseorang, seseorang dalam khayalan atau diri sendiri (Sarwono 2016).

Seperti halnya dalam penelitian Setiawan dan Nurhidayah menjelaskan bahwa antara pacaran dengan perilaku seksual pranikah mempunyai hubungan yang signifikan (Setiawan and Nurhidayah 2008). Hal tersebut senada dengan penelitian Yarni bahwa motivasi pacaran yang berorientasi fisik dan emosional berperan positif terhadap perilaku seksual remaja dalam berpacaran (Yarni 2005). Keinginan beraktivitas seksual merupakan keadaan yang sulit untuk dikendalikan, karena aktivitas seksual melibatkan beragam emosi yang terjadi pada mereka yang memiliki hubungan (berpacaran).

Terkait dengan perilaku seksual dalam berpacaran di atas, tinjauan hasil survei indikator kinerja RPJMN 2015 BKKBN menemukan persentase remaja laki-laki yang mengakui pernah mempunyai pacar sedikit lebih tinggi dibandingkan dengan perempuan $\quad(78,7 \%$ berbanding 76,2\%). Dalam mengungkapkan kasih sayang, $86,4 \%$ remaja mengakui berpegangan tangan, $31,7 \%$ cium bibir dan $12 \%$ meraba/merangsang, 
pengakuan pernah melakukan hubungan seksual pada remaja lakilaki $9,2 \%$ dan $2,9 \%$ terjadi pada remaja perempuan (Junaidi 2016).

Sementara itu, survey yang dilakukan oleh Rifka Annisa, sebuah lembaga Swadaya Masyarakat (LSM) menemukan kasus tindakan yang tidak diinginkan dalam aktivitas seksual paling banyak dialami oleh perempuan belum menikah yaitu berkomentar/mengirim pesan bernada seksual sebanyak $10 \%$, menyentuh atau meraba tubuh sebanyak $7,1 \%$, memperlihatkan gambar seksual 5,1\% dan memaksa untuk melakukan hubungan seksual sebanyak 2,8\% (Annisa 2016).

Dalam penelitian sebelumnya remaja perempuan ditemukan menunjukkan disposisi positif yang secara signifikan lebih tinggi terhadap perilaku seksual yang bertanggung jawab daripada laki-laki (Olapegba, Idemudia, and C.Onuoha 2013). Santrock menjelaskan bahwa dalam suatu hubungan secara umum dipercaya perempuan lebih kuat kepada perhatian, sementara laki-laki lebih tergoda dengan masalah seksual (Santrock 2003). Menurut McMormick \& Jessor dalam Santrock menjelaskan bahwa dalam berpacaran para laki-laki lebih banyak memberikan inisiatif, sementara perempuan mengikuti atau merespon gerakan yang dibuat oleh laki-laki. (Santrock 2003).

Hal tersebut di atas dipengaruhi oleh beberapa faktor seperti adanya teman sebaya mendorong dan mengajak remaja untuk berpacaran, adanya motivasi intrinsik dalam diri remaja seperti curiosity, dignity, puberty, peer acceptance juga mendorong remaja untuk berpacaran dan alat penghubung utama dalam melakukan komunikasi dengan teman, pacar dan orang tua remaja. Faktor pola asuh orang tua di rumah dan guru di sekolah juga mendukung remaja untuk berpacaran (Fuad 2014).

Kondisi yang sama menggejala pada remaja di SMA X Sleman. Berdasarkan survei awal yang dilakukan oleh peneliti terdapat beberapa remaja berpacaran dengan lawan jenis baik dalam satu lingkup sekolah atau luar lingkup sekolah, bahkan terdapat beberapa remaja di tahun sebelumnya terjemus dalam perilaku seksual pranikah. Selain itu, dari hasil pengamatan terhadap remaja yang berpacaran bahwa ketika pacaran pegangan tangan, pelukan dan lain sebagianya sebagai wujud kasih sayang terhadap lawan jenisnya. Sebuah pengakuan menyebutkan bahwa ketika berpacaran, melakukan perilaku-perilaku seksual mempunyai batasan-batasan tersendiri karena takut terjadi hal-hal yang pernah terjadi kepada temannya yaitu hamil beberapa waktu yang lalu.

Fenemona di atas menggambarkan betapa minimnya nilai-nilai etika dan moral. Namun tidak semua remaja termasuk pada penggambaran fenomena ini, melainkan faktor yang 
mempengaruhinya berbeda-beda.

Akibatnya, mental kejiwaannya sangat terpengaruh kondisi sebagian orang dewasa yang banyak mengatakan sesuatu yang tidak mereka kerjakan, atau saat mereka menyaksikan orang dewasa yang tidak beretika (Ridha 2006).

Membahas terkait dampak yang timbul akibat perilaku seksual pranikah mempunyai konsekuensi yang berbahaya bagi individu remaja. Diantara dampak tersebut yaitu melemahnya iman sehingga mudah terjerumus dalam perzinahan, menjadikan banyak angan-angan serta mengurangi produktivitas remaja tersebut (Dr. Iwan 2009), bertambahnya kasus HIV/AIDS, tinnginya kematian pada ibu muda, dan meluasnya kasus aborsi pada remaja belum menikah (Pratiwi and Basuki 2011). Selain itu, dampak psikologis yang terjadi di dalam diri seperti mudah marah, depresi, rasa bersalah yang berlebihan dan menimbulkan agresi (Mu`tadin dalam Pangestu, 2015).

Hukum Islam menjelaskan adanya larangan dalam mendekati zina seperti yang telah ditegaskan dalam Qs. Al-Israa ayat 32. Hal ini membuktikan bahwa dalam perilaku berpacaran tentu tidak terlepas dari perilaku seksual pranikah seperti kholwat dan ikhtilath, tentunya hal ini dianggap sebagai salah satu faktor yang memungkinkan terjadinya perbuatan zina.
Penjelasan dalam Qs. Al-Israa ayat 32 semakin terasingkan dan hanya dipahami secara teori saja, sehingga memicu seseorang untuk lebih leluasa dalam berperilaku seksual pranikah. Menanggapi hal tersebut, Aini berpendapat bahwa dalam mengurangi perilaku seks pranikah perlu adanya pemahaman tingkat agama (Aini, 2011). Kematangan beragama dan motivasi pacaran berorientasi keintiman fisik dan emosional berperan terhadap perilaku seksual remaja dalam berpacaran (Yarni, 2005). Pemahaman terhadap agama memberkan bukti bahwa remaja mampu dalam memahami dan mengetahui tentang agama. Oleh karena setiap individu sangat diperlukan untuk meningkatkan keimanan dan ketakwaan mereka sesuai dengan agama yang dianutnya. Selain itu, pemahaman terhadap keagamaan juga membuktikn bukti syukur atas fitrah yang telah Allah berikan kepada manusia sehingga pemahaman tersebut dapat membentuk perilaku yang lebih adaptif.

Manusia sebagai makhluk ciptaan Allah SWT yang paling sempurna merupakan hasil perpaduan antara jasmaniah dan ruhaniyah dengan mempunyai beberapa kecenderungan diantaranya kecenderungan untuk melakukan hal yang baik dan jahat (dkk 2010). Manusia juga dikaruniai potensi yang ada di dalam dirinya seperti potensi 
nur ilahiyah, ruh ilahiyah, nafs ilahiyah, qalb ilahiyah, aql ilahiyah, dan indrawi ilahiyah. Beberapa potensi tersebut dapat hadir dalam diri individu apabila individu tersebut memiliki keinginan untuk mencapai kesempurnaan hidup dan kehidupan keinsanan hakiki yang optimal (AdzDzaky 2006).

Hal tersebut di atas memberikan pemahaman bahwa ajaran-ajaran di dalam agama tentu akan bermanfaat dalam memberikan treatment terhadap perilaku maladaptif yang banyak menimpa manusia masa kini. Oleh karena itu, perlu adanya pendekatan bimbingan dan konseling islam sebagai upaya membantu konseli untuk mengembangkan fitrahnya dengan cara memprioritaskan iman, akal dan kemauan yang dilimpahkan oleh Allah (Maba, Hernisawati, and Mukhlishin 2017).

Seperti halnya Neilsen dalam penelitiannya yang mengintegrasikan teori konseling spiritual dan keagamaan dengan menggunakan pendekatan REBT Quranic kepada remaja dalam menghadapi tekanan akibat diperkosa. Neilsen mengajak konseli untuk lebih yakin kepada Allah tanpa paksaan sehingga ia mampu meningkatkan kesadaran seorang konseli agar lebih berfikir rasional dan mampu membuat keputusan (Neilsen 2005).

Proses pembersihan jiwa merupakan hal yang penting dalam mendorong lahirnya seorang muslim yang dapat membersihkan diri dari sifat-sifat buruk dan keji. Perilaku seks pranikah merupakan sifat buruk dan termasuk nafsu syahwat yang paling besar membebani manusia (alYamani 2012).

Sehingga dalam penelitian ini metode tazkiyatun nafs diasumsikan untuk mengisi hati dan jiwa manusia dengan emosi positif. Sehingga hati yang hampir saja sekarat akan dapat disembuhkan (An-Najar 2001). AlMusdiy mengatakan bahwa tazkiyatun nafs merupakan suatu cara untuk mendekatkan diri kepada Allah melalui pensucian diri dari berbagai kemaksiatan, sehingga dapat mencapai derajat Ihsan (Al-Musdiy 2005).

Berdasarkan penjelasan di atas, maka peneliti tertarik untuk mengupayakan perilaku seksual pranikah menjadi menurun, melalui pendekatan yang akan digunakan sebagai tritmen yakni REBT. Kecenderungan manusia berpikir rasional dan irasional merupakan salah satu sifat manusia di dalam bahasannya. REBT juga merupakan suatu pendekatan yang membelajarkan kembali konseli untuk memahami input kognitif yang menyebabkan gangguan emosional, mencoba mengubah pikiran konseli agar memberikan pikiran emosionalnya atau belajar mengantisipasi manfaat atau konsekuensi tingkah laku yang lebih efektif (Hartati 2017b). 
REBT menjadi pendekatan yang ideal dalam penelitian ini. Dasar filosofis dan asumsinya terhadap manusia begitu relevan dengan tema besar yang menjadi tujuan dalam penelitian ini. Landasan filosofi manusia tergambar dalam quotation dari Epictetus "Men are distrubed not by things, but by the views which they take of them"(manusia terganggu bukan karena sesuatu, tetapi pandangan terhadap sesuatu) (Patterson 2002). Hal tersebut berindikasi bahwa manusia memiliki kuasa atas dirinya untuk membawa pikiran dan perasaannya pada sebuah titik tertentu.

Dalam hal ini REBT mempunyai pandangan terhadap manusia bahwa kognitif atau proses berpikir mampu menciptakan gangguan emosional dalam diri individu. Pandangan terhadap manusia ini diasumsikan bahwa manusia didominasi oleh sistem berpikir dan sistem perasaan, semua hal tersebut selalu terhubung dengan psikis individu.

Tazkiytun nafs berbasis REBT dianggap tepat dari sisi keterkaitan teori untuk menurunkan kecenderungan perilaku seksual (Hartati 2018). Sikap terbuka atau tidaknya seseorang terhadap perilaku seksual pranikah dapat dilihat dari bagaimana remaja tersebut menjaga dan memelihara diri dari kecenderungan immoral (akhlakus sayyiah) (Effendi, n.d.). Pada tahap ini individu mampu menciptakan ideide baru dan kemudian mampu untuk mengaplikasikannya. Selain itu pada tahap ini individu telah memfokus pada pernyataan verbal dan mengevaluasi validitas logika mereka, tanpa membuat petunjuk dunia nyata. Individu pada tahap ini mampu untuk berpikir seperti orang dewasa serta mampu untuk memikirkan masa depannya dalam membuat keputusan.

Sementara itu, tercapainya proses tazkiyatun nafs dengan pendekatan REBT dalam menurunkan perilaku seks pranikah ini adalah bagaimana individu mampu menyeimbangkan antara jasad, jiwa dan ruhnya dalam berpikir menuju ranah mengevaluasi atas emosi dan perilakunya ketika suatu keadaan mempengaruhinya. Oleh karena itu, penelitian ini dikhususkan untuk mengetahui penurunan perilaku seksual pranikah remaja melalui tazkiyatun nafs berbasis REBT .

\section{METODE PENELITIAN}

Program bimbingan dan
konseling tazkiyatun nafs ini
merupakan program pensucian jiwa
seperti halnya yang telah dilakukan
oleh Hamjah (S. H. Hamjah 2010),
Abdullah (S. Abdullah 2014), Arifin
dan Hamjah (S. N. A. M. A. Hamjah
Salasiah Hanin, n.d.) dan Salleh dan
Khafidz (Khafidz 2016), sebagai
upaya membantu memberdayakan
kembali potensi yang ada di dalam
diri individu serta mengaktifkan
kembali keimanan dan ketakwaan
hingga kembali berkembang dan
berfungsi sebagaimana mestinya.


Berdasarkan permasalahan penelitian yang telah disebutkan di atas maka penelitian ini menggunakan metode penelitian quasi experimental dengan menggunakan desain nonequivalent pretest and posttest control group design.

Penelitian ini menetapkan subjek pada remaja kelas XI di SMA X Sleman dengan usia 16-18 tahun yang berjumlah 11 orang. Kriteria subjek dalam penelitian ini yaitu memiliki ciri perilaku seksual pranikah dengan kategori tinggi berupa sexual fantasies, masturbation, touching, kissing, petting dan sexual intercourse; Subjek penelitian menyadari bahwa dirinya saat ini berada dalam suatu krisis moral, memiliki pikiran negatif; Subjek penelitian bersedia mengikuti seluruh sesi bimbingan dan konseling yang ada, yakni sebanyak 4 (empat) sesi. Secara keseluruhan subjek penelitian ini berjumlah 11 remaja.

Pengumpulan data dilakukan dengan menggunakan skala untuk mengetahui tingkat perilaku seksual pranikah remaja dengan mengacu pada teori yang dikemukakan oleh Kinsey dan Simandjuntak. Aspekaspek ini dijabarkan dalam pernyataan favorabel dan unfavorabel.

Skala perilaku seksual pranikah yang telah dimodifikasi tersebut diujicobakan kepada remaja di luar subjek penelitian sejumlah 30 remaja. Reliabilitas skala ini diestimasi dengan analisis cronbach's alpha.
Koefisien cronbach's alpha yang dihasilkan adalah 0,894 dengan koefisien korelasi item total yang telah terkoreksi bergerak dari angka 0,324 - 0,824. Dari 64 item yang diuji validitas terdapat 18 butir soal dinyatakan tidak valid, selanjutnya item terpakai untuk penelitian ini sejumlah 46.

Perlakuan yang diberikan kepada subjek adalah sebuah bimbingan dan konseling tazakiyatun nafs dengan menggunakan teknik pendekatan REBT. Desain bimbingan bimbingan dan konseling tazakiyatun nafs akan dilakukan dengan menggunakan alat bantu berupa modul bimbingan dan konseling tazakiyatun nafs dengan pendekatan REBT dan skala penelitian. Pelaksanaan penelitian dilakukan dalam 4 kali pertemuan dengan durasi 60 sampai 75 menit. Lama penelitian menyesuaikan jadwal sekolah.

Tahapan dalam bimbingan dan konseling tazakiyatun nafs dengan menggunakan teknik pendekatan REBT adalah sebagai berikut: Pertama, memahamkan kepada konseli bahwa perasaan dan perilaku dipicu oleh adanya kepercayaan dan pikiran. Kedua, Menunjukkan bagaimana kepercayaan dan pikiran seseorang mungkin tertutup. Pada kesempatan ini konselor meminta konseli bercerita tentang Antecedent event (A) seperti apa, Belief (B) seperti apa, dan Emotionl consequence (C) seperti apa. Ketiga, Mengajarkan konseli bagaimana 
melawan dan merubah kepercayaan irasional, kemudian menggantinya dengan kepercayaan yang lebih rasional. Keempat, Membantu konseli merubah perilaku konseli.

Pre test pada subjek penelitian diberikan pada kesebelas subjek penelitian dari masing-masing kelompok sebelum dilakukan tritmen. Selanjutnya pengisian Post test bagi kelompok eksperimen dan kelompok kontrol. Pelaksanaan post test merupakan langkah setelah pemberian tritmen pada kelompok eksperimen yang bertujuan untuk mengetahui perilaku seksual pranikah remaja. Begitupula kelompok kontrol, meskipun tidak mendapatkan tritmen namun tetap mendapatkan post test.

\section{HASIL PENELITIAN DAN PEMBAHASAN}

Berdasarkan hasil uji statistik dengan menggunakan teknik analisis uji Ancova satu arah (One way Ancova) pada skala perilaku seksual pranikah antara pre test dan post test diberikan bimbingan dan konseling memperlihatkan adanya perbedaan yang signifikan antara kelompok yang memperoleh bimbingan dan konseling tazkiyatun nafs berbasis REBT dengan kelompok yang tidak diberikan bimbingan dan konseling.

Dengan mengendalikan skor pretest perilaku seksual pranikah remaja, diperoleh nilai $F_{\text {hitung }}$ lebih besar daripada $F_{\text {tabel }}(36,810>4,46)$. Dengan demikian, $\mathrm{H}_{0}$ pertama ditolak pada nilai signifikan 0,000 . Hal ini memiliki pengertian bahwa pada tingkat kepercayaan $95 \%$ dapat dinyatakan terdapat hubungan linier antara pretest dengan posttest perilaku seksual pranikah remaja. Besarnya efek perlakuan tazkiyatun nafs berbasis REBT terhadap penurunan perilaku seksual pranikah pada remaja sebesar $66 \%$ pada kolom Partial Eta Squared. Nilai ini menunjukkan varians pada variabel perilaku seksual pranikah remaja setelah perlakuan 66\%-nya dapat dijelaskan oleh tazkiyatun nafs berbasis REBT.

Selanjutnya selain uji analisis ANCOVA dalam penelitian ini juga digunakan uji Two Way Anova untuk mengetahui adanya variabel moderator yang mempengaruhi efektivitas tazkiyatun nafs berbasis REBT. Berdasarkan hasil uji analisis tersebut menunjukkan bahwa efektivitas bimbingan dan konseling tazkiyatun nafs berbasis REBT dalam menurunkan perilaku seksual pranikah remaja tidak bergantung kepada jenis kelamin remaja. Hal ini sesuai dengan hasil Uji Anava Dua Jalur diperoleh nilai $\mathrm{F}$ sebesar 1,666 dengan angka signifikansi 0,213. Dengan demikian tidak ada efek interaksi yang signifikan.

Perilaku seksual pranikah merupakan bentuk dorongan seksual baik dengan lawan jenis maupun dengan sesama jenis yang dilakukan oleh para remaja sebelum mereka menikah. Banyak remaja masa kini memiliki pola pikir bahwa aktivitas 
seksual merupakan salah satu pembuktian cinta dan kasih sayang dimulai dari hal kecil, tetapi semakin lama bisa melakukan perilaku yang berbahaya secara seksual.

Berbagai penelitian tentang pensucian jiwa oleh Abdullah melalui Model Taubat al-Ghazali (M-TaG), menunjukkan bahwa dengan mengidentifikasi delapan tahap dalam proses taubat al-Ghazali yaitu, bimbingan akidah, bimbingan syariah, bimbingan akhlak, taubat muhasabah, taubat muatabah (penyesalan), taubat muaqabah, taubat mujahadah dan istiqamah, menghasilkan pengaruh yang signifikan untuk membantu seseorang pernah zina berubah dalam proses taubat (S. Abdullah 2014).

Selain itu, penelitian Neilsen yang menggabungkan terapi konseling spiritual dan keagamaan dengan menggunakan pendekatan REBT Quranic kepada mahasiswa dalam menghadapi tekanan akibat diperkosa oleh pacarnya (Neilsen 2005). Dalam hal ini perasaan yang dialami konseli yaitu merasa berdosa, berpikiran negatif, tidak masuk akal dan menganggap dirinya kotor sebagai representasi terhadap rasa malunya dan hilang harga diri mengakibatkan ia harus memilih untuk berhenti belajar dan mencoba bunuh diri.

Karzon mengungkapkan bahwa mensucikan jiwa dari kecenderungan berbuat buruk dan dosa serta menumbuhkan fitrah yang baik di dalamnya sehingga dapat menegakkan istiqamahnya dan mencapai derajat ihsan (Karzon 2012). Dengan demikian melalui berpikir rasional individu akan menyadari konsekuensi-konsekuensi perbuatan dan pengontrolan dorongan emosionalnya dalam melakukan kecenderungan buruk dan dosa (M. A. Abdullah 2002). Hal ini karena cara berfikir dan berperasaan seseorang dapat mengakibatkan perubahan yang berarti dalam cara berperasaan dan berperilaku (Winkel 1991).

Penjelasan-penjelasan dari hasil penelitian di atas sesuai dengan tujuan penelitian ini yaitu tazkiyatun nafs berbasis REBT berpengaruh terhadap penurunan perilaku seksual pranikah pada remaja. Hal ini diwujudkan dengan melatih dirinya untuk bisa menjauhkan diri dari kecenderungan perilaku buruk yakni seksual pranikah dan mengisi dengan perilaku terpuji.

Penelitian di atas menjelaskan seseorang yang dapat bertanggung jawab sebagai makhluk ciptaan Allah SWT dibumi diberikan tugas untuk selalu menjalankan perintah sesuai dengan ajaran yang terdapat di dalam al-Qur`an dan As-Sunnah serta dapat menjauhkan dirinya dari larangan Allah SWT dalam hal ini adalah perilaku seksual pranikah. Dalam hukum islam perilaku seksual sebelum menikah merupakan dosa besar. Seperti halnya telah dijelaskan dalam Qs. Al-Israa ayat 32 tentang 
adanya larangan dalam mendekati zina.

Setelah melalui uji Two way Anava, terbukti bahwa jenis kelamin tidak mempengaruhi terhadap kefektifan tazkiyatun nafs berbasis REBT dalam menurunkan perilaku seksual pranikah pada remaja. Fakta empirik ini dapat dijelaskan dengan perbedaan jenis kelamin tidak lagi menjadi isu sebagai variabel penting. Dalam suatu hubungan secara umum dipercaya perempuan lebih kuat kepada perhatian, sementara laki-laki lebih tergoda dengan masalah seksual (Santrock 2003). Menurut McMormick \& Jessor dalam Santrock menjelaskan bahwa dalam berpacaran para laki-laki lebih banyak memberikan inisiatif, sementara perempuan mengikuti atau merespon gerakan yang dibuat oleh laki-laki. (Santrock 2003).

Meskipun proporsi perilaku seksual antara laki-laki dan perempuan sama, namun karena secara sosial laki-laki cenderung lebih banyak memiliki kebebasan dibandingkan dengan perempuan, selain itu orang tua juga cenderung lebih bersikap protektif pada perempuan. Hal ini tidak dapat dilepaskan dari pengaruh teknologi informasi dan komunikasi serta besarnya keinginan remaja untuk mencoba-coba yang semakin mempertipis perbedaan perilaku lakilaki dan perempuan. Hal ini menunjukkan bahwa perilaku seksual pranikah pada remaja tidak ditentukan oleh sesuatu yang bersifat kodrati, seperti jenis kelamin, melainkan lebih oleh faktor yang diusahakan (acquired factor). Implikasinya perlu adanya pengawasan dari orang tua dan guru tanpa membedakan jenis kelamin karena sangat beresiko terhadap masa depan baik pada remaja laki-laki maupun remaja perempuan jika terjadi hal-hal yang tidak diinginkan.

Banyak faktor yang mendukung terbuktinya hipotesis dalam penelitian ini, faktor dari luar materi pelatihan yaitu penyampaian konselor yang baik dan tidak monoton, faktor, konseli yang mudah diajak bekerja sama turut mendukung terbuktinya hipotesis yang diajukan dalam penelitian ini. Konseli penelitian sangat antusias dalam mengikuti kegiatan bimbingan dan konseling ini karena merupakan pengalaman pertama bagi subjek. Guru Bimbingan dan konseling berperan dalam kelancaran penelitian baik sebagai konselor maupun dengan memberikan sarana dan prasarana dalam mengkondisikan lingkungan dan mendukung jalannya kegiatan tazkiyatun nafs berbasis REBT yang telah dilaksanakan.

Berdasarkan pada fokus permasalahan yang diajukan, konteks penelitian secara keseluruhan mampu dipertanggungjawabkan oleh peneliti, karena hipotesis yang diajukan terbukti sehingga pembahasan yang dikemukakan pada penelitian ini tidak terlalu melebar karena permasalahan 
yang telah dibahas di awal dan teori yang telah dikemukakan semua representatif mampu menjelaskan dinamika kausalitas antara perilaku seksual pranikah remaja dengan tazkiyatun nafs berbasis REBT yang diberikan.

Hasil penelitian ini diharapkan memberikan sumbangan atau referensi ilmiah bagi bimbingan dan konseling umumnya atau bimbingan dan konseling islam untuk menurunkan perilaku seksual pranikah pada remaja melalui tazkiyatun nafs berbasis REBT. Materi dalam kegiatan bimbingan dan konseling ini dapat dijadikan sebagai sebuah terapi umum maupun islami untuk menurunkan perilaku seksual pranikah remaja. Kondisi lingkungan yang mendukung serta kerjasama dari orang tua, pihak sekolah dan masyarakat akan meminimalkan remaja berperilaku negatif dalam berpacaran sehingga kaedah berpikir rasional yang diajarkan kepada konseli dapat digunakan dalam menghadapi masalah lain. Konseli merasa dirinya mempunyai kemampuan intelektual dan kemajuan dari cara berpikir.

\section{SIMPULAN}

Hasil analisis data statistik menyimpulkan bahwa perilaku seksual pranikah efektif dapat diturunkan melalui tazkiyatun nafs berbasis REBT. Adapun setelah dilaksanakan perlakuan dengan menggnakan tazkiyatun nafs berbasis
$R E B T$, jenis kelamin tidak memiliki pengaruh terhadap efektivitas tazkiyatun nafs berbasis REBT Efek perlakuan tazkiyatun nafs dengan berbasis REBT terhadap penurunan perilaku seksual pranikah remaja sebesar 0,66.

Meskipun penelitian ini menunjukkan bahwa penurunan perilaku seksual pranikah melalui tazkiyatun nafs berbasis REBT dinyatakan efektif akan tetapi intensitas dan durasi waktu yang digunakan untuk layanan bimbingan dan konseling dan pengaruh lain yang diduga mempengaruhi efektivitas tazkiyatun nafs berbasis REBT dalam menurunkan perilaku seksual pranikah remaja menjadi keterbatasan penelitian ini, seperti tingkat IQ, tingkat motivasi remaja, dan kecakapan berbahasa.

\section{DAFTAR PUSTAKA}

Abdullah, M. Amin. 2002. Antara AlGhazali Dan Kant: Filsafat Etika Islam. Bandung: Mizan.

Abdullah, Salhah. 2014. "Model Taubat Al-Ghazali (M-TaG)" VOL.13 (SPECIAL EDITION) 2014.

Adz-Dzaky, Hamdani Bakran. 2006. Konseling Dan Psikoterapi Islam. Fajar Pustaka Baru.

Al-Musdiy, Muhammad Yasir. 2005. Qad Aflaha Man Zakkaha. Bairut: Dârul Basya'ir AlIslamiyah.

An-Najar, Amir. 2001. Ilmu Jiwa Dalam Tasawuf. Jakarta: Pustaka Azam. 
Annisa, Rifka. 2016. "Laporan Survey Pengalaman Hidup Perempuan Nasional."

Desmita. 2012. Psikologi Perkembangan. Bandung: PT Remaja Rosda Karya.

dkk, Rohana Hamzah. 2010. "Spiritual Education Development Model," 1.

Dr. Iwan. 2009. Masturbasi. Yogyakarta: C.V Andi offset.

Effendi, Djohan. n.d. Ulumul Quran No. 8, Volume II,1991.

Fuad, Wa Ode Fatmawati. 2014. "Perilaku Pacaran Remaja Di SMA Negeri ' $\mathrm{X}$ ' Baubau." Program Pasca Sarjana Fakultas Kedokteran: Universitas Gajah Mada.

Hamjah, Salasiah Hanin. 2010. "Bimbingan Spiritual Menurut Al-Ghazali Dan Hubungannya Dengan Keberkesanan Kaunseling: Satu Kajian Di Pusat Kaunseling Majlis Agama Islam Negeri Sembilan (PK MAINS)" ISL MIYY T32 (2010).

Hamjah, Siti Nazratul Ain Mohd Arifin, Salasiah Hanin. n.d. "Aplikasi Tazkiyah Al-Nafs Menerusi Mujahadah Al-Nafs Dalam Kaunseling" Fikiran Masyarakat, Vol. 5, No.2, 2017: 2017.

Hartati, Sri. 2017a. "Konsep Pendekatan Rational Emotive Behavior Therapy (Rebt) Berbasis Islam Untuk Membangun Perilaku Etis Siswa" Volume VIII No. 2, Juli 2017.

. 2017b. "Konsep Spiritual Parenting Dengan Pendekatan Konseling Behavioristik Dalam Membentuk Moral
Anak Usia Sekolah Dasar." Bina Gogik: Jurnal Ilmiah Pendidikan Guru Sekolah Dasar 4 (1). http://ejournal.stkipbbm.ac.id/ index.php/pgsd/article/view/1 02 .

.2018. "Tazkiyatun nafs as an Effort to Reduce Premarital Sexual Behavior of Adolescents." Islamic Guidance and Counseling Journal $1 \quad$ (1): 33. https://doi.org/10.25217/igcj.v 1i1.207.

Hurlock, E.B. 2007. Psikologi Perkembangan. Jakarta: Erlangga.

Junaidi. 2016. "Tinjauan Hasil Survai Indikator Kinerja RPJMN 2015 BKKBN Provinsi Jambi, Disampaikan Pada Rapat Koordinasi BKKBN Provinsi Jambi," 2016.

Karzon, Anas Ahmad. 2012. Tazkiyatun nafs. Jakarta: Akbar Media.

Khafidz, Nik Siti Khadijah Nik Salleh dan Hasanah Abd. 2016. "Penyucian Jiwa Melalui Pendekatan Muhasabah Dalam Penghayatan Shalat" Fikiran Masyarakat, ISSN: 2338-512X. Vol. 4, No. 2.

Komalasari, Gantina. 2014. Teori Dan Teknik Konseling. Jakarta: PT Indeks.

Maba, Aprezo Pardodi, Hernisawati, and Ahmad Mukhlishin. 2017. "Bimbingan Dan Konseling Islam Solusi Menjaga Dan Meningkatkan Kesehatan Mental" Jurnal Konseling GUSJIGANG Vol. 3 No. 2.

Neilsen, Stevan Lars. 2005. A Mormon Rational Emotive 
Behavior Therapist Attempt

Qura'nic Rational Emotive

Bahavior Therapy. Dlm.

Richards. P.S \&

Bergin.A.E(Pnyt.). A Case

Book for a Spiritual Strategy

in Counseling and

Psychotherapy.

WashingtonD.C: American

Psychological Association.

Olapegba, Peter O, Erhabor S

Idemudia, and Uchenna

C.Onuoha. 2013. "Gender

Differences In Responsible

Sexual Behavior Of In-School

Adolescents" Gender and

Behavior, volume 11, issue 1, january.

Patterson, Kaslow. 2002. "Comprehensive Handbook of Psychotherapy" Volume 2, Cognitive Behavioral Aplakilakiches Canada: Jhon Willey \& Sons, Inc.

Pratiwi, Niniek Lely, and Hari Basuki. 2011. "Hubungan Karakteristik Remaja Terkait Risiko Penularan HIV-AIDS Dan Perilaku Seks Tidak Aman Di Indonesia" Buletin Penelitian Sistem Kesehatan, Vol. 14 no. 4 oktober.

Ridha, Arkam. 2006. Manajemen Gejolak: Panduan Ampuh Orangtua Mengelola Gejolak Remaja. Bandung: Syaamil Cipta Media.

Santrock. 2003. Adolescence: Perkembangan Remaja. Jakarta: Erlangga.

Sarwono, Sarlito W. 2016. Psikologi Remaja. Jakarta: PT Raja Grafindo Persada.

Setiawan, Rony, and Siti Nurhidayah. 2008. "Pengaruh Pacaran Terhadap Seks Pranikah"
Jurnal Soul, Vol. 1, No. 2, September.

Winkel, WS. 1991. Bimbingan Dan

Konseling Di Institusi Pendidikan. Jakarta: Grasindo.

Yamani, Syekh Yahya ibn Hamzah al-. 2012. Pelatihan Lengkap Tazkiyatun nafs. Jakarta: Zaman.

Yarni, Linda. 2005. "Perilaku Seksual Remaja Dalam Berpacaran Ditinjau Dari Kematangan Beragama Dan Motivasi Pacaran Yang Berorientasi Keintiman Fisik Dan Emosional." Universitas Gajah Mada. 